\title{
LIFE WORLD OF YOUNG FAMILY IN SPACE OF MULTICULTURAL REGION: SUSTAINABILITY AND RISKS OF DISINTEGRATION
}

\author{
Artamonova Candidate of Sociology, lecturer at the Department of Regional Sociology \\ Yana \\ and Modeling of Social Processes, \\ Viktorovna \\ Institute of Sociology and Regional Studies, Southern Federal University \\ (160, Pushkinskaya St., Rostov-on-Don, 344006, Russian Federation). \\ E-mail: janaserduchenko@mail.ru \\ Gafiatulina Candidate of Sociology, Associate Professor, Doctoral Candidate \\ Natalya \\ at the Department of Regional Sociology and Modeling of Social Processes \\ Khalilovna \\ at the Institute of Sociology and Regional Studies, Southern Federal \\ University (160, Pushkinskaya St., Rostov-on-Don, 344006, \\ Russian Federation). E-mail: gafiatulina@yandex.ru
}

\begin{abstract}
The paper discusses an urgent topic of sociological analysis - the stability of the life world of a young family in a multicultural environment. The transformation processes of modern society have a significant impact on the formation of the value attitudes of young people, which are reflected in the changing attitudes of young people towards family and family behavior. It has been found that the volatility and the riskiness of the modern world force young people to adapt to modern reality, to build the family's behavior in such a way as to keep its life world intact. It can be concluded that overcoming the risk of disintegration of the life world of a young family should occur through risk reflection on the part of such agents as family, education, government and public organizations, mass media, as well as young spouses themselves. It is evident that such a comprehensive riskreflection can make the life world of a young family stable.
\end{abstract}

Keywords: life world, values, attitudes, young people, young families, risk, life-world of a young family, family behavior.

The development of modern society largely depends on the development of such a socio-demographic group as youth. Changes in the social environment entail changes in the views of modern young people on social reality. Since modern Russian society is going through a huge number of socio-economic, political and socio-cultural transformations, young people are forced to re-construct social reality based on these changes. The attitude of young people to the social institution of the family is also being transformed, which in turn leads to the emergence of new models of family behavior. For the majority of young people, the family becomes an instrumental value [1], informal marriages (cohabitation) are currently not denied by young people [2], and when choosing a family model, young people most often focus on a two-child family model, but in reality, the one-child model of a young family prevails [3].

The issues of youth are relevant among modern researchers [4]. Particular importance is attached to such a direction in the study of youth as the attitude of young people towards the family and the problems of a young family. Analysis of the relevant research works proves the popularity of this direction. Analyzing the problems of a young family, scientists investigate life strategies, lifestyle, value orientations and attitudes of a young family $[5,6,7]$. Considering a young family and its problems, researchers turn to the reproductive behavior of a young family and the social health of spouses $[8,9]$. The aspects considered by scientists relate to a complex concept - the life world of a young family. 
According to D. B. Vorontsov and A.V. Vorontsova, the current situation in Russian society is characterized by the presence of many unfavorable factors affecting the increase in the number of risks of family breakdown. While considering risk groups in two aspects: 1) risks at the society level due to violation of generally accepted social rules and norms; 2) risks at the level of an individual, when family members do not have the normal living conditions required for a full life and development; it was concluded that the risks for the family (including the young family) are "such factors of life in society, which cause negative consequences in one way or another, violation of the functions of the family, as well as threats to the social, financial and / or physical safety of the family (or its individual members), emanating from specific people or society as a whole" [10].

The volatility and riskiness of the modern world force young people to adapt to modern reality, to build family behavior in such a way as to keep its life world intact. In risk - taking environment, an urgent issue is aimed at considering the stability of the life world of a young family and preventing the risks of its breakdown.

By recreating social reality, people endow it with their own interpretations. A. Schütz gives the following definition of social reality - it is the sum of objects and events that can be observed in the socio-cultural world in the form interpreted by people living everyday life among other people associated with them by many relationships and interactions [11]. Transformations of social reality also cause changes in the views of young people on its objects.

Concerning the life world of a young family, we note that this is "a subjective model of social reality, reflecting the ideas of young spouses about the family, their family values, attitudes and practices determined by factors of the macro and micro social environment" [12].

The structure of the life world includes young spouses (actors), the social environment with hidden riskgenerating factors of impact on the life world, value orientations and attitudes of young spouses, as well as the social behavior of a young family.

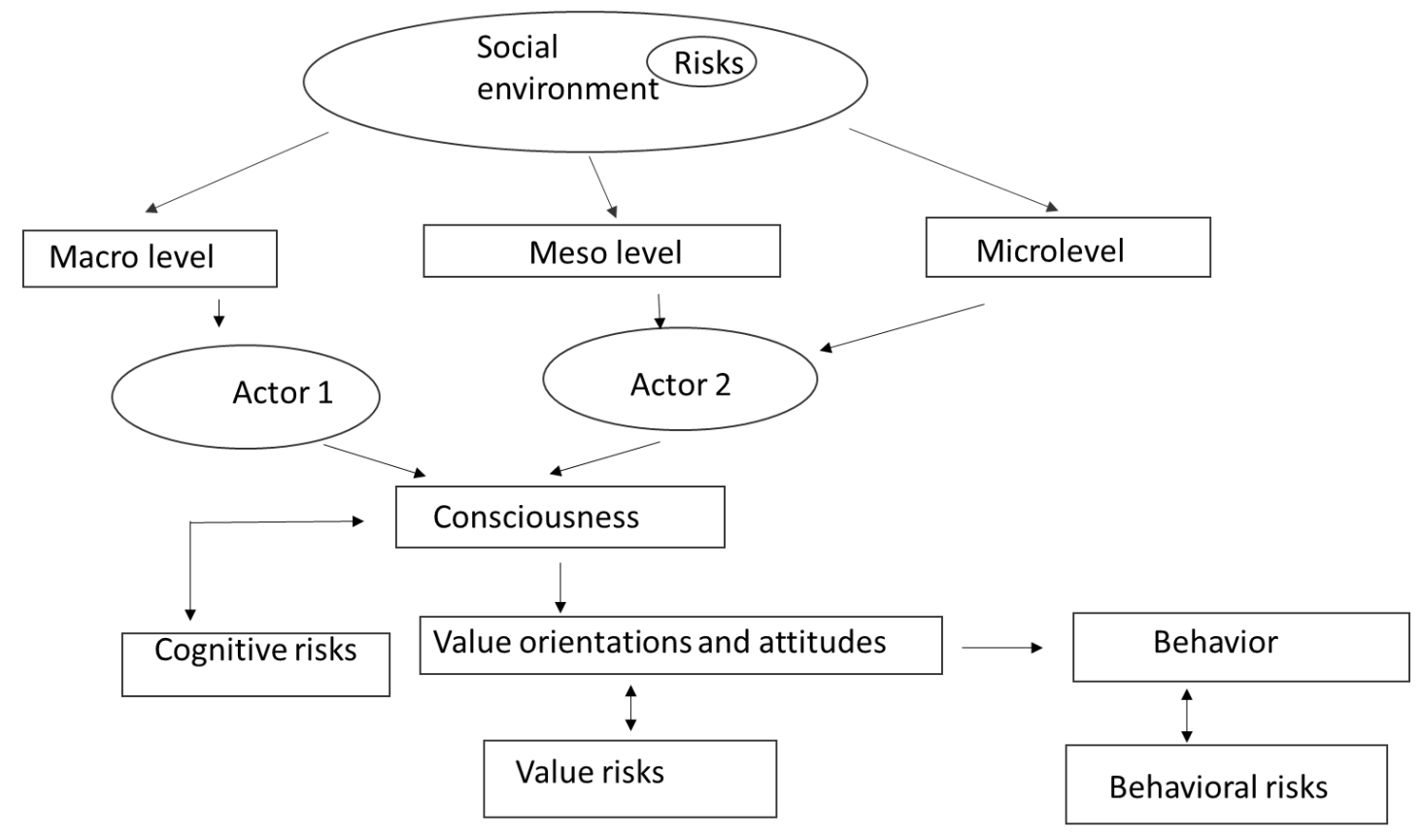

\section{Figure: 1. Structure of the life world of a young family (based on the concept of the sociology of life by Zh.T. Toshchenko and the riskological concept of Yu.A. Zubok)}

The life world of a young family is based on traditional models of family behavior, if there is stability in the development of society. But, as we have already emphasized, Russian society is a risky space that contains a conflict potential for absolutely all components of the life world, and can have a significant impact on the stability of the life world, and sometimes lead to its disintegration.

As part of this work, we turn to the life world of a young family in a multicultural space, since, in our opinion, a multicultural environment is more risky. To measure the life world of a young family, we used indicators shown in Figure 2. 


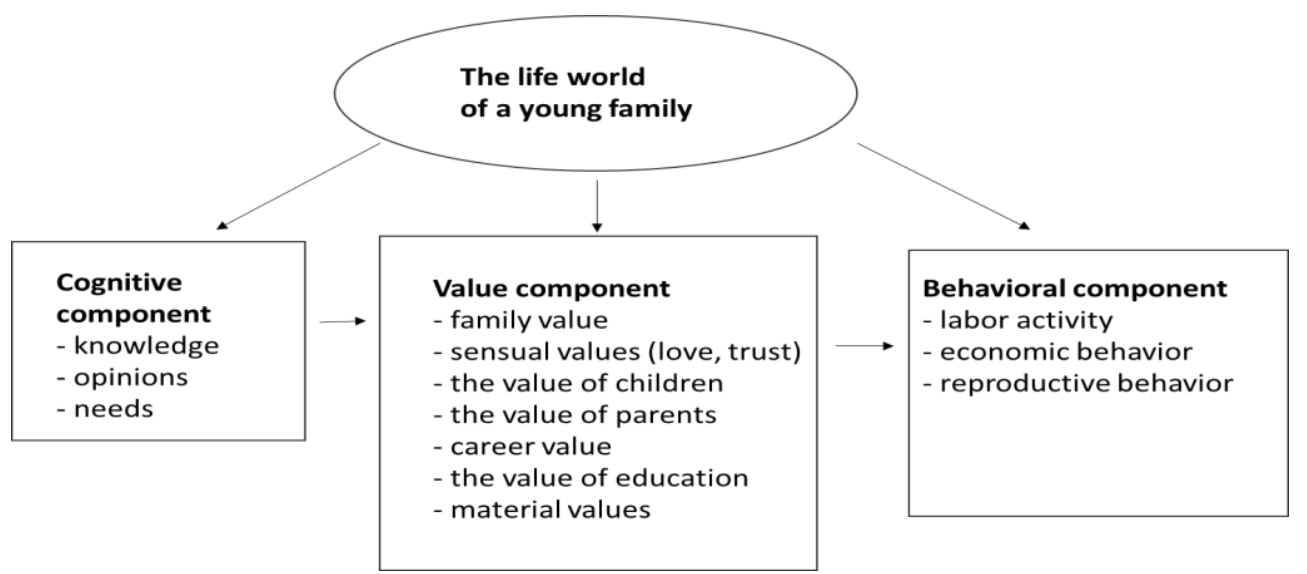

Figure: 2. Structure of measuring the life world of a young family

Having analyzed the data obtained in the course of the sociological research "Life World of Young Family in Rostov Region", we can assert that the life world of a young family contains the following risks: cognitive risks, value risks and risks associated with the behavior of young spouses.

Due to the fact that young spouses surveyed noted that at present the level of knowledge of young people about family and family relations tends to decrease, there are risks of a cognitive order. Young families attributed this kind of risk to a decrease in the level of family culture (10.4\%), low protection in terms of family and juvenile law (2.8\%), as well as a loss of religiosity $(2.7 \%)$.

Value risks are associated with the devaluation of the family, its transition from terminal to instrumental value. In the Rostov region, young spouses noted a tendency towards the destruction of family values, although in general the stability of family values and traditions is typical for the Rostov region. The results of the conducted empirical research emphasize the traditional views of young spouses on the form of family relations $(89.2 \%)$ and the main motives for creating a family are love $(90 \%)$ and children $(17 \%)$.

During the survey, young families also noted that they face behavioral risks. Risks of changes in the behavior of spouses are associated with the transformation of the quality and lifestyle of young spouses. Such changes entail changes in the behavior of young people. The discrepancy between the cognitive-value ideas of young spouses and real social practices causes behavioral risks. About $20 \%$ of respondents are afraid of the risk of economic instability, which cause risks associated with reproductive behavior (16.9\%). A large number of spouses noticed the dependence of the reproductive attitudes of the spouses on the financial situation of the young family. In addition, young families indicated that there are gender contradictions in household behavior. Modern young women very rarely act only in the role of a homemaker; they actively participate in economic activities and provide for their families on an equal basis with men, therefore, they demand from men a fair division of household duties, which sometimes causes conflict situations.

The analyzed data show that the sources of destruction of the life world of a young family in a multicultural region are cognitive, value and behavioral risks. Cognitive and value risks entail behavioral risks of destroying the life of a young family. In this regard, the search for sustainable development of the life world of a young family in a multicultural region should be based on the strategies aimed at overcoming the risks of destruction of the life world within the cognitive, value and behavioral components of the life world structure.

That is, the formation of a sustainable life world of a young family in the space of a multicultural region requires young spouses to have a conscious understanding of the risks, as well as the ability to prevent them. The behavior of a young family must be reflected at the level of spouses. In addition to risk-reflection at the level of spouses, such a procedure should also be carried out by social systems, which will help reduce the risks of disintegration of the life world of a young family [12, 13, 14].

Risk reflection is manifested in macro-strategies and micro-strategies of the cognitive, value and behavioral order. Micro-strategies and macro-strategies for minimizing and overcoming risks are based on the activities of the following agents: family, education, government and public organizations, the media.

Thus, the stability of the life world of a young family depends on quality reflection on the part of all the agents involved. Such measures make it possible to achieve successful activities aimed at supporting young families and family policy. In turn, it is evident that risk reflection on the part of young spouses is very important and urgently necessary, which will enable the young spouses themselves to actively participate in the development of programs aimed at supporting young families. 


\section{References}

1. Gorshkov M.K. Russian society as it is: (experience of sociological diagnostics). In 2 volumes. Vol. 1. Ed. 2nd, rev. and add. Moscow: New Chronograph, 2016. 416 p.

2. Roshchina Ya. M., Maltseva M.A. Informal marriage in Russia in 2000-2014 [Electronic resource] // Bulletin of the Russian Monitoring of the Economic Situation and Health of the Population of the Higher School of Economics (RLMS HSE). 2016. Issue. 6. URL: https: // www. hse.ru/data/2016/07/28/1118935935/Vestnik\%20RLMS-HSE_2016.pdf (accessed 06 December 2019).

3. Demographic forecast until 2030 [Electronic resource] Federal State Statistics Service URL: http://www.gks.ru/wps/wcm/connect/rosstat_main/rosstat/ru/materials/news/doc_127253911207 (accessed 06 December 2019).

4. Russian youth in the mirror of sociology. By the results of many years of research: [monograph] / Gorshkov M.K., Sheregi F.E. Moscow: FNISTs RAN, 2020, pp. 10-11.

5. Rostovskaya T.K. Creation of a student family: motivation and life strategies of members of young student families (results of an all-Russian interuniversity study) // Bulletin of Nizhny Novgorod University named after Lobachevski N.I. Series: Social Sciences. 2015. No. 4 (40). URL: https://cyberleninka.ru/article/n/sozdanie-studencheskoy-semi-motivatsiya-i-zhiznennye-strategiichlenov-molodyh-studencheskih-semey-itogi-vserossiyskogo (accessed 17 January 2021).

6. Presnyakova-Osipova I.V. The image and quality of family life // Power. 2013. No. 5. URL: https://cyberleninka.ru/article/n/obraz-i-kachestvo-zhizni-semi (accessed 17 January 2021).

7. Sorokina E.S. Life strategies of a young family: a sociological analysis. Abstract. Diss. Cand. Sociol. Sciences. M., 2007.21 p.

8. Khairullin R.R., Soloviev M.M. Factors of reproductive behavior of a young family: Orthodox values // VEPS. 2015. No. 2. URL: https://cyberleninka.ru/article/n/faktory-reproduktivnogo-povedeniya-molodoy-semipravoslavnye-tsennosti (accessed 17 January 2021).

9. Gafiatulina N.Kh., Vereshchagina A.V., Samygin S.I. Social health of a young family: indicators and assessment levels // Humanities, socio-economic and social sciences. 2017. No. 8-9.

10. Vorontsov D.B., Vorontsova A.V. Social risks affecting the modern family // Personality, family and society: issues of pedagogy and psychology. 2014. No. 45, pp. 35-40.

11.Schutz A. Selected: A world glowing with meaning. M., Russian political encyclopedia 2004, p. 55.

12.Serdyuchenko Ya.V. The life world of a young family: features of formation and risks of destruction (based on materials from the Rostov region): author. Diss. Cand. Sociological sciences 22.00.04 / Serdyuchenko Ya.V., Rostov-on-Don, 2018.

13. Gafiatulina N.Kh., Kasyanov V.V., Samygin P.S., Samygin S.I. Russian society in self-isolation. Social effects and consequences of the COVID-19 pandemic. Monograph. Moscow, 2020.178 p.

14.Karapetyan E.A., Gafiatulina N.Kh., Efimova V.M., Yaksa N.V., Luginina A.G., Prokhorenko O.N. Cyber socialization as a factor of influence on the social health of student youth in a modern educational environment under the development of a global information society // Revista Gênero e Direito. 2020. T. 9. № 4. C. 830-845.

Артамонова Яна Викторовна, кандидат социологических наук, преподаватель кафедры региональной социологии и моделирования социальных процессов Института социологии и регионоведения, Южный федеральный университет (344006, Россия, г. Ростов-на-Дону, ул. Пушкинская, 160).

E-mail: janaserduchenko@mail.ru

Гафиатулина Наталья Халиловна, кандидат социологических наук, доцент, докторант кафедры региональной социологии и моделирования социальных процессов Института социологии и регионоведения, Южный федеральный университет (344006, Россия, г. Ростов-на-Дону, ул. Пушкинская, 160).

E-mail: gafiatulina@yandex.ru

\section{ЖИЗНЕННЫЙ МИР МОЛОДОЙ СЕМЬИ В ПРОСТРАНСТВЕ ПОЛИКУЛЬТУРНОГО РЕГИОНА: УСТОЙЧИВОСТЬ И РИСКИ РАСПАДА Аннотация}

Авторы работы затрагивают актуальную тему социологического анализа - устойчивость жизненного мира молодой семьи в поликультурном пространстве. Трансформационные процессы, которые происходят в современном обществе, оказывают существенное влияние на формирование иенностных установок молодежи, которые отражаются на изменении взглядов молодых людей на семью и семейное поведение. На основе проведенного анализа авторы статьи отмечают, что изменчивость и рискогенность современного мира подталкивают молодых людей приспосабливаться к современной реальности, выстраивать поведение семьи так, чтобы сохранять ее жизненный мир в целостности. Среди рисков жизненного мира выделены: когнитивные, ценностные, поведенческие риски. По мнению авторов, преодоление рисков распада жизненного мира молодой семьи должно происходить за счет риск-рефлексии со стороны таких агентов, как семья, образование, государственные и общественные организации, СМИ, а также самих молодых супругов. Именно такая комплексная риск-рефлексия сможет сделать жизненный мир молодой семьи устойчивым.

Ключевые слова: жизненный мир, ценности, ценностные ориентации, социальные установки, молодежь, молодая семья, риск, жизненный мир молодой семьи, семейное поведение. 